also seeking to relax its Wildlife and National Parks Act of 1993 to enable culling of the Mauritian flying fox (Pteropus niger), a protected bat species that is classified as endangered by the International Union for Conservation of Nature.

Even some apparently positive actions - such as restoring habitats in the island's national park - are being mismanaged, resulting in rising costs that compromise restoration progress (F. B. V. Florens and C. Baider Restor. Ecol. 21, 1-5; 2013). F. B. Vincent Florens University of Mauritius, Réduit, Mauritius. vin.florens@uom.ac.mu

\section{Sustain the future by doing more with less}

The term sustainability originally conceived to mean doing more with less - is now used to describe development that meets current needs without compromising those of future generations (World Commission on Environment and Development Our Common Future, 1987). As food shortages increase and the global population expands, it is time to revisit the original concept of sustainability.

In accepting the idea of sustainable development as politically correct and allencompassing, scientists and policy-makers have created a world in which 'sustainability' can be used both to defend and to attack environmental policy. Sustainability needs to be rebranded, for example by shifting consumer focus from greenness to payback and efficiency, and by differentiating between the private costs of policy implementation and the social cost of non-implementation (M. Csutora and Á. Zsóka J. Consum. Policy 34, 67-90; 2011).

The world has changed since 1987, and that 'future generation' has been born. Policies that promote sustainability should aim to provide the best life for as many people as possible - by doing more with less.

Brian G. Fitzgerald University of Limerick, Ireland. brian.g.fitzgerald@ul.ie

\section{Dead language still alive for botanists}

I disagree with Frank Udovicic's contention that there is no scientific merit in using Latin, rather than English, for botanical descriptions and diagnoses (Nature 492, $356 ; 2012)$. The meaning of descriptive terms in Latin will not change, precisely because it is a dead language. Living languages alter over time and can lead to subtle shifts in interpretation.

For example, the English word 'lavender' can describe either the colour of Lavandula angustifolia flowers or a shade of pale purple, whereas the botanical Latin term, caesius, has the standardized meaning 'pale blue, with a slight mixture of grey' (W. T. Stearn Botanical Latin, 1966).

Both Latin and English diagnoses are permitted under the International Code of Nomenclature for algae, fungi and plants. The International Botanical Congress has refused to make diagnoses in English compulsory. Botanists should therefore be free to use either or both languages.

Adam T. Halamski Institute of Paleobiology, Warsaw, Poland. ath@twarda.pan.pl

\section{Transmission studies resume for avian flu}

In January 2012, influenza virus researchers from around the world announced a voluntary pause of 60 days on any research involving highly pathogenic avian influenza $\mathrm{H} 5 \mathrm{~N} 1$ viruses leading to the generation of viruses that are more transmissible in mammals ${ }^{1}$. We declared a pause to this important research to provide time to explain the public-health benefits of this work, to describe the measures in place to minimize possible risks, and to enable organizations and governments around the world to review their policies (for example, on biosafety, biosecurity, oversight and communication) regarding these experiments.

During the past year, the benefits of this important research have been explained clearly in publications ${ }^{2-7}$ and meetings ${ }^{8-10}$. Measures to mitigate the possible risks of the work have been detailed ${ }^{11-13}$. The World Health Organization has released recommendations on laboratory biosafety for those conducting this research ${ }^{14}$, and relevant authorities in several countries have reviewed the biosafety, biosecurity and funding conditions under which further research would be conducted on the laboratory-modified $\mathrm{H} 5 \mathrm{~N} 1$ viruses $^{10,15-17}$. Thus, acknowledging that the aims of the voluntary moratorium have been met in some countries and are close to being met in others, we declare an end to the voluntary moratorium on avian-flu transmission studies.

The controversy surrounding $\mathrm{H} 5 \mathrm{~N} 1$ virus-transmission research has highlighted the need for a global approach to dealing with dual-use research of concern. Developing comprehensive solutions to resolve all the issues will take time. Meanwhile, $\mathrm{H} 5 \mathrm{~N} 1$ viruses continue to evolve in nature.

Because $\mathrm{H} 5 \mathrm{~N} 1$ virustransmission studies are essential for pandemic preparedness and understanding the adaptation of influenza viruses to mammals, researchers who have approval from their governments and institutions to conduct this research safely, under appropriate biosafety and biosecurity conditions, have a public-health responsibility to resume this important work. Scientists should not restart their work in countries where, as yet, no decision has been reached on the conditions for $\mathrm{H} 5 \mathrm{~N} 1$ virus transmission research. At this time, this includes the United States and US-funded research conducted in other countries. Scientists should never conduct this type of research without the appropriate facilities, oversight and all necessary approvals.

We consider biosafety level 3 conditions with the considerable enhancements (BSL-3+) as outlined in the referenced publications ${ }^{11-13}$ to be appropriate for this type of work, but recognize that some countries may require BSL- 4 conditions in accordance with applicable standards (such as Canada). We fully acknowledge that this research - as with any work on infectious agents - is not without risks. However, because the risk exists in nature that an $\mathrm{H} 5 \mathrm{~N} 1$ virus capable of transmission in mammals may emerge, the benefits of this work outweigh the risks.

Ron A. M. Fouchier Erasmus Medical Center, Rotterdam, the Netherlands.

Adolfo García-Sastre Icahn School of Medicine at Mount Sinai, New York, USA.

Yoshihiro Kawaoka* University of Wisconsin-Madison, Wisconsin, USA, and University of Tokyo, Japan.

kawaokay@svm.vetmed.wisc.edu ${ }^{*}$ On behalf of 40 co-authors (see go.nature.com/ed3qkc for a full list).

1. Fouchier, R. A. M. et al. Nature 481, 443 (2012).

2. Fouchier, R. A. M., Herfst, S. \& Osterhaus, A. D. M. E. Science $\mathbf{3 3 5}$, 662-663 (2012).

3. Herfst, S. Osterhaus, A. D. M. E. \& Fouchier, R. A. M. J. Infect. Dis. 205 1628-1631 (2012).

4. Kawaoka, Y. Nature 482, 155 (2012)

5. Yen, H.-L. \& Peiris, J. S. M. Nature 486, 332-333 (2012)

6. Morens, D. M., Subbarao, K. \& Taubenberger, J. K. Nature $\mathbf{4 8 6}$, 335-340 (2012).

7. Fauci, A. S. \& Collins, F. S. Science 336, 1522-1523 (2012).

8. WHO. Report on Technical Consultation on H5N1 Research Issues (WHO, 2012); available at go.nature.com/ka2bw4.

9. NSABB. Statement of the Nationa Science Advisory Board for Biosecurity, March 2012; available at go.nature.com/fapzkh.

10.Agenda for Workshop on Gainof-Function Research on Highly Pathogenic Avian Influenza H5N1 Viruses, 17-18 December 2012, Bethesda, Maryland; available at go.nature.com/tr7r9z

11.García-Sastre, A. mBio 3, e00049-12 (2012).

12.Imai, M. et al. Nature 486, 420-428 (2012).

13. Herfst, S. et al. Science 336 , 1534-1541 (2012)

14.WHO. Guidance on risk control measures for $\mathrm{H} 5 \mathrm{~N} 1$ transmission research, July 2012; available at go.nature.com/4z4yzg.

15.Public Health Agency of Canada. Advisory on Transmissible H5N1 Viruses, 1 February 2012; available at go.nature.com/jfutoz.

16.COGEM. Letter in response to influenza research at Erasmus MC (in Dutch), 21 March 2012; available at go.nature.com/ef5lix.

17.US Government Policy for Oversight of Life Sciences Dual Use Research of Concern (2012); available at go.nature.com/8rkjap. 